\title{
İktisadi Büyüme ve Yolsuzluk İlişkisi: Türkiye için Ampirik Bir İnceleme
}

Araştırma Makalesi /Research Article

\section{Sinan ERDOGAN ${ }^{1}$}

ÖZ:Bu çalışmanın temel amacı iktisadi büyüme-yolsuzluk ilişkisini Türkiye'de 1995-2018 dönemi için sınır testi yaklaşımıyla araştırmaktır. Çalışmadan elde edilen bulgular şöyle sıralanabilir; (a) açıklayıcı değişkenlerin durağanlık özellikleri I(1) ve I(0) olmak üzere karışıktır, (b) sınır testi sonuçlarına göre kişi başı yatırımlar, kişi başı hane halkı tüketim harcamaları ve ticari açıklık iktisadi büyümeyi pozitif etkilemektedir, (c) diğer taraftan yolsuzluk, enflasyon ve iktisadi büyüme arasında istatistiksel olarak anlamlı bir iliş̧ki yoktur. Bu bağlamda Türkiye ekonomisinde yolsuzluk iktisadi büyüme sürecini etkilememekle beraber ne "tekerdeki kum" nede "tekerdeki yağ"' dır.

Anahtar Kelimeler: Yolsuzluk, Ekonomik Büyüme, ARDL, Türkiye

JEL Siniflandirmasi: 047, D73

\section{Economic Growth and Corruption Nexus: An Empirical Study for Turkey}

ABSTRACT: The main purpose of this study is to examine economic growth-corruption nexus in Turkey for the period of 1995-2018 by bound test approach. The empirical findings are as follows: (a) the regressors have a mixed stationarity levels such as $I(1)$ and $I(0),(b)$ according to the bound test results, per capita investments, per capita house hold consumption expenditures and trade openness have a positive effect on economic growth, (c) on the other hand, there is no statistically significant relationship between corruption, inflation and economic growth. In this context, corruption does not affect economic growth in Turkey, and it is neither a "sand in wheel" nor "grease in wheel".

Keywords: Corruption, Economic Growth, ARDL, Turkey

JEL Codes: O47, D73

Geliş Tarihi / Received: 28/02/2020

Kabul Tarihi / Accepted: 16/07/2020

${ }^{1}$ Dr. Öğr. Üyesi, Hatay Mustafa Kemal Üniversitesi, İktisadi ve İdari Bilimler Fakültesi, İktisat Bölümü, sinanerdogan@mku.edu.tr, orcid.org/0000-0003-3491-8234. 


\section{Giriş}

Yolsuzluk olgusu, günümüzde hem azgelișmiș hem de gelișmiș ülkelerin gündemlerini işgal eden bir konudur. Yolsuzluk; salt iktisadi ve politik yönlere sahip olmamakla beraber aynı zamanda sosyolojik, hukuki ve kültürel boyutu olan bir gerçeklik olup, bu açıdan yalnızca politik veya iktisadi bakış açısı ile engellenemeyecek kadar karmaşık bir süreçtir. Yolsuzluğun kavramsal açıdan ele alınacak olursa; Dünya Bankası kavramsal olarak yolsuzluğu "şahsi çıkarlar ve kazançlar uğruna kamu gücünün istismar edilmesi" olarak tanımlamaktadır (World Bank, 1997:8). Yolsuzluğun sürecinde salt kamu görevlilerinin rol almadığ1 veya kamu gücünü istismar ederek gerçekleştirilebilen bir olgu olmadığ 1 , kamusal aktivitelerin dışında da kişisel çıkarlar uğruna, kişilerin şahsi çıkarlarını maksimize etmek için bu yola bașvurabildiği göz önünde bulundurulduğunda bu tanımın oldukça yetersiz bir tanım olduğu göze çarpmaktadır. Diğer taraftan Uluslararası Şeffaflık Örgütü (Transparency International) ise yolsuzluk kavramını "karar alıcı tarafindan şahsi çıkar ve kazancını güvenceye almak için sahip olduğu gücü ve otoriteyi istismar etmesi" biçiminde ifade ederek, yolsuzluk olgusuna daha geniş bir bakış açısı getirmiştir (Transparency International, 2019a).

Literatürde, genellikle az gelişmiş ülkeler bağlamında incelenen ve irdelenen yolsuzluk olgusu, salt az gelişmiş ülkeler için bir problem olmamakla beraber aynı zamanda gelişmiş ülkelerin politik ve iktisadi işleyişini de etkilemektedir. Bu hususu 2018 yılında Birleşmiş Milletler (BM) Güvenlik Konseyi'nin 8346 nolu toplantısında BM genel sekreteri António Guterres "Yolsuzluk, zengin ve yoksul, kuzeyde ve güneyde, gelişmiş veya gelişmekte olan tüm ülkelerde var olan bir problemdir." sözleriyle ifade etmiştir (United Nations, 2018). Bu olguyu daha somut hale getirmek gerekirse, Uluslararası Şeffaflık Örgütü tarafindan 2017 yılında, 119 ülke ve bölgede küresel yolsuzluk eğilimini ölçmeye yönelik olarak yapılan anket sonucuna göre, Sahraaltı Afrika bölgesinde yaşayan insanların yaklaşı1k \%68' i yolsuzluk olgusundan ve yolsuzluk ile mücadelenin yetersizliğinden şikâyet etmekte iken, Avrupa'da bu oran \%50 gibi yine ciddi oranda yüksek bir rakamdır (Transparency International, 2017: 4). Bu bağlamda ortalama olarak azgelişmiş bir bölgeden göreli olarak gelişmiş bir bölgeye geçildiğinde değişen şeyin yolsuzluğun kendisi değil, yalnızca ölçü miktarı olduğu söylenebilir. Nitekim Dünya Ekonomik Forumu (World Economic Forum), yolsuzluk olgusunun küresel maliyetini yaklaşık 3,6 trilyon dolar olarak hesaplamış olup, bu rakam küresel gayrisafi yurtiçi hasılanın yaklaşık \%5'ine denk gelmektedir. Bu rakamlar 1şığında yolsuzluğun yalnızca ülkelerin iktisadi yapıları için değil, oluşan küresel iktisadi sistem için de bir yük olduğu sonucuna varılabilir (Johnson, 2018).

Diğer taraftan yolsuzluğun ekonomik işleyişe etkisi konusunda ise iki yaklaşım geliştirilmiştir. Bunlardan ilkine göre yolsuzluk, özellikle sermaye birikiminin yetersiz olduğu azgelişmiş ülkelerde sermayenin tek elde toplanmasını sağlayarak 
yatırımlar için gerekli kaynağın oluşturulmasını hızlandırmaktadır. Böylece yatırımlar vasıtasıyla gayrisafi yurtiçi hasıla artışı mümkün hale gelecektir. Ayrıca etkinsiz bir bürokratik sistemde yatırım ve girişim sürecini kısaltma ve iktisadi aktiviteleri hızlandırma adına yolsuzluk adeta bir katalizör görevi görebilmektedir. Yolsuzluğun iktisadi işleyiş için genel kanının aksine zararlı bir husus olmadığını savunan bu görüş politik iktisat literatüründe "Etkin Yağlama Hipotezi" olarak adlandırılmaktadır (Huntington, 1968, Kaufman ve Wei, 1999; Dreher ve Gassebner, 2013). Bu görüşün aksini savunanlara göre ise yolsuzluk iktisadi işleyiş ve ekonomik büyüme üzerindeki en büyük tehditlerden birisidir (Shleifer and Vishny, 1978, Mauro, 1995). Dünya Bankası eski başkanlarından J. Wolfensohn bu olguyu "yolsuzluk iktisadi gelişmeyi engelleyen bir kanser gibidir" sözleri ile ifade etmekte iken, Wei (1999) ise "yolsuzluk ekonomik gelişme önündeki en büyük engeldir" sözleriyle ifade etmektedir. Bu bağlamda yolsuzluğun, ekonomide işleri kolaylaştıran bir yă̆ olmamakla beraber, aksine iktisadi işleyişin çarklarının dönmesini zorlaştıran ve engelleyen adeta bir "çakıl taşı/kum” niteliğinde olduğu sonucuna varılabilir.

$\mathrm{Bu}$ bilgiler 1şığında yolsuzluğun iktisadi işleyiş üzerindeki etkisi konusunda literatürde net bir bulunmadığ 1 sonucuna ulaşılabilir. Bu çalışmada Türkiye'de iktisadi büyüme ve yolsuzluk ilişişi 1995-2018 dönemi için veya gecikmesi dağıtılmış otoregresif sınır testi (Autoregressive Distributed Lag Bound (ARDL) Test) yöntemi ile araştırılmıştır. Çalışmanın ikinci bölümünde literatür araştırması yapılmış, üçüncü bölümünde model ve veri seti tanıtılmış, analizle kullanılan ampirik yöntemler ve elde edilen ampirik bulgular ele alınmıştır, son olarak dördüncü kısımda ise çalışmanın sonuçlandırılmış ve politika önerileri yapılmıştır.

\section{Literatür Araştırması}

Yolsuzluk ve ekonomi ilişkisi erken dönemde politik ve felsefi bağlamda genişçe tartışılmış olmakla beraber, Mauro'nun (1995) öncü çalışmasından bu yana araştırmacılar tarafından ampirik olarak da araştırılmaya başlanmıştır. Mauro (1995) çalışmasında, yolsuzluğun yatırımlar üzerinde azaltıcı etki yapmak suretiyle iktisadi büyümeyi yavaşlattığı sonucuna erişmiştir. Ayrıca çalışmada kurumsal etkinsizliğin iktisadi büyümeyi azalttığı sonucuna ulaşılmıştır. Mauro'nun çalışmasını izleyen dönemde yolsuzluk-iktisadi büyüme ilişkisi hem çok ülkeli hem de tek ülkeli örneklemlerle ve farklı tahmin yöntemleriyle araştırılmıştır. $\mathrm{Bu}$ çalışmalardan çok ülkeli olan veya Türkiye dışında farklı ülkeleri örneklem olarak kullanan çalışmalar Tablo 1' de sunulmuştur. Diğer taraftan Türkiye dışında farklı örneklemler kullanan çalışmaların sayısı oldukça fazla olmakla beraber, genellikle çok ülkeli çalışmaların yapıldığ 1 görülmektedir. Çalışmaların bulgularına göre yolsuzluğun iktisadi büyümeyi negatif etkilediğine dair büyük oranda bir uzlaşının varlığından söz edilebilir. 
Tablo 1: Literatür Tablosu

\begin{tabular}{|c|c|c|c|}
\hline Yazar(lar) & Örneklem-Dönem & Yöntem & Bulgular \\
\hline Mauro (1995) & 67 Ülke, 1980-1985 & $\begin{array}{l}\text { EKK ve İki Aşamalı } \\
\text { EKK }\end{array}$ & $\begin{array}{c}\text { Büyüme Üzerinde } \\
\text { Yatırımlar Yoluyla } \\
\text { Negatif Etki } \\
\end{array}$ \\
\hline Ehrlich ve Lui (1999) & 152 Ülke, 1969-1992 & Regresyon Analizi & Negatif Etki \\
\hline $\begin{array}{l}\text { Del Monte ve } \\
\text { Papagni (2001) }\end{array}$ & $\begin{array}{l}\text { İtalya } 20 \text { Bölge, } \\
\text { 1963-1991 }\end{array}$ & $\begin{array}{c}\text { İki Aşamalı EKK, } \\
\text { Sabit Etkiler ve } \\
\text { Rassal Etkiler Modeli }\end{array}$ & Negatif Etki \\
\hline Akçay (2002) & 54 Ülke, 1960-1995 & EKK & Negatif Etki \\
\hline Drury vd. (2006) & $\begin{array}{l}\text { 100'den fazla ülke, } \\
\text { 1982-1997 }\end{array}$ & EKK & $\begin{array}{c}\text { Demokratik } \\
\text { Ülkelerde İlişki Yok } \\
\begin{array}{c}\text { Demokratik Olmayan } \\
\text { Ülkelerde Negatif } \\
\text { İlişki }\end{array} \\
\end{array}$ \\
\hline $\begin{array}{l}\text { Gökalp ve Baldemir } \\
(2006)\end{array}$ & 147 Ülke, 1996-2002 & $\begin{array}{c}\text { Kümeleme ve Panel } \\
\text { Veri Analizi }\end{array}$ & Negatif Etki \\
\hline Swaleheen (2011) & $1984-2007$ & $\begin{array}{c}\text { Genelleştirilmiş } \\
\text { Momentler Yöntemi } \\
\text { (GMM) ve Sistem } \\
\text { GMM } \\
\end{array}$ & $\begin{array}{c}\text { Düşük (Yüksek) } \\
\text { Yolsuzluk Seviyesine } \\
\text { Büyüme Üzerinde } \\
\text { Negatif (Pozitif) Etki }\end{array}$ \\
\hline Erkal vd. (2014) & $\begin{array}{c}\text { OECD ve AB } \\
\text { Ülkeleri, 1995-2012 }\end{array}$ & $\begin{array}{c}\text { Panel Sinır Testi } \\
\text { (ARDL) }\end{array}$ & Negatif Etki \\
\hline Sofuğlu vd. (2017) & $\begin{array}{c}\text { Yeni Sanayileşmiş } \\
\text { Ülkeler, 2001-2014 }\end{array}$ & $\begin{array}{c}\text { Fully Modified EKK- } \\
\text { Dinamik EKK }\end{array}$ & Negatif Etki \\
\hline $\begin{array}{l}\text { Altunç ve Yıldırım } \\
\text { (2017) }\end{array}$ & 47 Ülke & EKK & Negatif Etki \\
\hline $\begin{array}{c}\text { Cieslik ve Goczek } \\
(2018)\end{array}$ & 142 Ülke, 1994-2014 & GMM & Negatif Etki \\
\hline $\begin{array}{c}\text { Sharma ve Mitra } \\
(2019)\end{array}$ & 103 Ülke, 1996-2015 & $\begin{array}{l}\text { GMM ve Sistem } \\
\text { GMM }\end{array}$ & Negatif Etki \\
\hline
\end{tabular}

Not: Tablo yazar tarafindan oluşturulmuştur.

Diğer taraftan Türkiye için yapılan çalışmalar ele alınacak olursa; Karagöz ve Karagöz (2010) Türkiye için 1980-2005 yıllarını kapsayan çalışmasında, Granger Nedensellik yöntemi ile araştırmış olup çalışma sonucuna göre yolsuzluktan iktisadi büyümeye doğru bir nedensellik söz konusu değilken, iktisadi büyümeden yolsuzluğa doğru bir nedensellik ilişkisi söz konusudur. Diğer taraftan kamu harcamaları ile yolsuzluk arasında herhangi bir nedensellik ilişkisine rastlanılmamıştır. Arslan ve Sağlam (2011) çalışmasında Türkiye'de 1970-2007 dönemi için yolsuzluk-yatırımlar arasındaki ilişkiyi eşbütünleşme yaklaşımı ile incelemiştir. Elde edilen bulgulara göre yolsuzluk ve yatırımlar arasında uzun dönemli pozitif bir ilişki vardır. Beşel ve Savaşan (2014) Türkiye'de yolsuzlukiktisadi büyüme ilişkisini 1985:01- 2012:11 dönemi için yapısal kırılmaları dikkate alan birim kök ve eşbütünleşme yöntemleriyle incelemiştir. Bulgulara göre değişkenler arasında eşbütünleşme ilişkisi olmamakla beraber, TodaYamamoto nedensellik testine göre ekonomik büyümeden yolsuzluğa doğru tek 
yönlü bir nedensellik ilişkisi tespit edilmiş, yolsuzluktan ekonomik büyümeye doğru ise herhangi nedensellik ilişkisi tespit edilmemiştir.

Literatürde de görüldüğü üzere Türkiye dışında örneklemlerde yolsuzluk-iktisadi büyüme ilişkisini inceleyen çalışmaların sayısı bir hayli fazla ve ciddi bir literatür oluşmuşken, Türkiye özelinde yapılan çalışmaların sayısı ise oldukça kısıtlıdır. Ayrıca nedensellik yaklaşımına dayanan çalışmalarda, yolsuzluktan iktisadi büyümeye doğru herhangi bir nedensellik tespit edilememiştir. $\mathrm{Bu}$ olgunun ötesinde bu yöntemler ile nedenselliğin yönü ve büyüklügünü tespit etmek ise ne yazık ki olanaklı olmamaktadır. Bu bağlamda ilgili yöntemlerle Türkiye'de yolsuzluğun iktisadi büyüme üzerindeki etkisine karar verme ve buna göre uzun erime yönelik politikalar oluşturma ne yazık ki olanaklı değildir. Diğer bir ifadeyle yolsuzluğun tekerin dönüşünü kolaylaştıran bir yağ mı, yoksa zorlaştıran bir kum mu olduğu tespit edilememektedir. Bu çalışmada Türkiye'de yolsuzluk ve iktisadi büyüme arasındaki uzun dönemli ilişki 1995-2018 dönemi için ARDL yaklaşımı ile araştırılmaktadır. Bu yönüyle çalışma, literatürde yer alan diğer çalışmalardan ayrışmaktadır.

\section{Model, Veri Seti, Ampirik Yöntem ve Bulgular}

\subsection{Model ve Veri Seti}

Çalışmada Türkiye için yolsuzluk ve iktisadi büyüme ilişkisini 1995-2018 dönemi için incelemek amacıyla aşağıdaki logaritmik doğrusal model kullanılmıştır:

$$
\ln Y_{t}=\beta_{0}+\beta_{1} \ln c o r_{t}+\beta_{2} \ln I_{t}+\beta_{3} \ln C_{t}+\beta_{4} \ln e n f_{t}+\beta_{4} \ln t r_{t}+\varepsilon_{t}
$$

$\mathrm{Bu}$ denklemde $Y_{t}$ kişi başı reel gayrisafi yurtiçi hasılayı, cor yolsuzluk algı seviyesini, $I$ yatırımları (reel fiyatlarla gayrisafi sermaye oluşumu), $C$ tüketim harcamalarını (kişi başı hane halkı reel tüketim harcaması), enf enflasyonu (tüketici fiyatları, \%), tr ise ticari açıklık oranını (gayrisafi yurtiçi hasıla yüzdesi) göstermekte olup $\mathrm{t}=1+2+\ldots+24$ ' tür. Modelde büyüme üzerine etkisi araştırılan ana değişken yolsuzluk değişkeni olup, yatırım ve tüketim harcamaları büyüme fonksiyonunun ana bileşenlerinden olması ve Türkiye ekonomisinde iktisadi büyümenin temel teşvikçilerinden olması nedeniyle ihmal edilmiş değişken sapmasını engellemek adına modele dahil edilmiş kontrol değişkenleridir. Diğer taraftan Türkiye ekonomisi, uzun yıllar boyunca fiyat istikrarsızlıkları ve yüksek enflasyon ile mücadele etmek zorunda kalmıştır. Kimi dönemlerde enflasyon ile mücadelede önemli başarılar elde edilse de son yıllarda, enflasyonda bir yükseliş trendinin söz konusu olduğu söylenebilir. Enflasyon aynı zamanda hanı halk1 geliri ve göreli fiyatları etkileme yoluyla dış rekabet gücünü etkilemesi nedeniyle Türkiye ekonomisi açısından önemli bir makro iktisadi göstergedir. Özellikle 1980 sonrası Türkiye ekonomisinde ihracata dayalı büyüme modeli benimsenmesi nedeniyle iktisadi büyüme için önem kazanan ihracat bileşeninin, reel döviz kuru kanalıyla enflasyondan etkilendiği söylenebilir. Ayrıca ihracata dayalı büyümeyle beraber Türkiye'de üretebilmek ve ihraç edebilmek için enerji gibi temel 
girdilerin ithalatı da artmış hem ithalat hem de ihracat iktisadi büyüme sürecinin önemli belirleyicilerinden olmuş ve milli gelir içindeki payı artmıştır. Bu nedenle hem enflasyon hem de ticari açıklık değişkeni modele ayrıca kontrol değişkenleri olarak eklenmiş olup iktisadi değişkenlere ilişkin verilen Dünya Bankası Dünya Gelişme Göstergeleri (World Bank, 2019) veri tabanından elde edilmiştir. Yolsuzluk verisi olarak ise Transparency International (2019b) tarafindan önerilen CPI (Corruption Perception Index (CPI) kullanılmıştır.

\subsection{Ampirik Yöntem ve Bulgular}

Çalışmada değişkenlerin entegrasyon derecelerini belirlemek adına Genişletilmiş Dickey-Fuller (1981) birim kök testi (ADF) ve Kwiatkowski vd. (1992) (KPSS) tarafından önerilen durağanlık testi kullanılmıştır ARDL yaklaşımının değişkenlerin entegrasyon derecelerine aşırı duyarlı olması nedeniyle, sapmalı hipotez kabulünden kaçınmak adına yokluk hipotezinde birim kök ve durağanlığı test eden iki farklı test prosedürü kullanılmıştır. ADF yaklaşımında kullanılan regresyon modeli şöyle tanımlanabilir (Enders, 2014: 218):

$$
\Delta y_{t}=\alpha_{0}+\gamma y_{t-1}+\alpha_{1} t+\sum_{i=1}^{p} \beta_{i} \Delta y_{t-i}+\varepsilon_{2 t}
$$

Burada $\alpha_{0}$, sabit; $t$ doğrusal zaman trendi; $\Delta$, birinci sıra farkı; $p$, gecikme sayısı ve $\varepsilon_{2 t}$ hata terimidir. ADF yaklaşımında yokluk hipotezinde "Birim kök vardır $(\gamma=0)$ " görüşü, "Seri durağandır $\gamma<0$ " görüşüne karşı test edilmektedir. Diğer taraftan KPSS durağanlık testinin kullanmış olduğu regresyon modeli aşağıdaki gibi tanımlanabilir (Kwiatkowski $v d .$, 1992: 161):

$$
y_{t}=\delta t+r_{t}+\varepsilon_{3 t}
$$

Burada $r_{t}=r_{t-1}+u_{t} \quad$ ve $\mathrm{u}_{\mathrm{t}} \sim \operatorname{iid}\left(0, \sigma_{\mathrm{u}}{ }^{2}\right) \quad$ ve $\quad \varepsilon_{\mathrm{t}} \sim \operatorname{iidN}\left(0, \sigma^{2}\right) \quad$ dir. Ayrica $t$, deterministik trend parametresini, $r$ rassal süreci (random walk) ve $\varepsilon_{3 t}$, durağan hata terimini ifade etmektedir. KPSS yaklaşımında ADF yönteminden farklı olarak testinde yokluk hipotezi; sabitli modelde $\sigma_{\mathrm{u}}{ }^{2}=0$, "seri ortalama durağandır" biçiminde, sabitli ve trendli modelde ise $\sigma_{u}{ }^{2}=0$, "seri trend durağandır", şeklinde önerilmiştir.

Değişkenler arasındaki uzun dönem ilişkileri araştırmak için Pesaran ve Shin (1999) ve Pesaran, Shin ve Smith (2001) tarafından geliştirilen ARDL sınır testi yöntemi kullanılmıştır. ARDL sınır testi yaklaşımının avantajları şöyle siralanabilir (Ozturk ve Acaravci, 2013: 263-64; Acaravc1 vd. 2019: 9): i) ARDL sınır testi için değişkenlerin entegrasyon derecelerinin homojen olması zorunluluğu olmamakla beraber entegrasyon derecesinin I(1)'den büyük olması Halinde Pesaran vd. (2001) ve Narayan (2005)'ın geliştirdiği kritik değerler geçersiz olmakta, dolayısıyla yöntem kullanılabilir olmaktan çıkmaktadır.. ii) ARDL yaklaşımı iyi derecede küçük örneklem özelliklerine sahip olup bazı 
regresörlerin içsellik sergilemesi durumunda dahi etkin bir tahmincidir. iii) Hem bağımlı değişken hem de regresörler için heterojen gecikme seviyeleri belirlenebilmektedir. iv) ARDL kapsaminda kısa ve uzun dönem parametre katsayıları, indirgenmiş denklem kullanılarak tahmin edilebilmektedir. ARDL yaklaşımı iki aşamadan oluşmaktadır. İlk aşamada değişkenler arası eşbütünleşme ilişkisi, kısıtsız hata düzeltme modeli (ECM) vasıtasıyla sınanmaktadır. Modelde eşbütünleşme ilişkisi olması durumunda ikinci aşamaya geçilmekte ve ARDL kapsamında kısa ve uzun dönem katsayılar hesaplanmaktadır.

ARDL sınır testi kapsamında kullanılan kısıtsız hata düzeltme modeli (ECM), aşağıdaki denklemde (4) gösterilmiştir:

$$
\Delta Y_{t}=\beta_{0}+\sum_{i=1}^{p} \beta_{n i} \Delta X_{t-i}+\delta_{n} X_{t-1}+\varepsilon_{t}
$$

Burada $Y_{t}$ bağımlı değişkeni, $X$ açıklayıcı değişkenler setini, $\varepsilon_{t}$, artığı, $\Delta$ ise değişkenlerin birinci farkını temsil etmektedir. ARDL sınır testi kapsamında optimal gecikme uzunlukları bilgi kriteri kullanmak koşuluyla belirlenmektedir. ARDL sinır testi, yokluk hipotezinin $\left(H_{0}: \delta_{n}=0\right)$ alternatif hipoteze $\left(H_{1}: \delta_{n} \neq 0\right)$, $(n=1,2,3,4$.) karşı, F-testi veyahut Wald testi sınamasını temel alır. Tahmin edilen test istatistiği, kritik üst sınır değerinin üzerinde kaldığ 1 durumda, modelde eşbütünleşme ilişkisi olmadığına dayanan Ho hipotezi reddedilir. Tahmin edilen test istatistiği kritik alt sınır değerin altında kaldığı durumda, Modelde eşbütünleşme ilişkisi olmadığına dayanan Ho hipotezi kabul edilir (Ozturk ve Acaravci, 2013: 264, Acaravc1 vd. 2019: 9).

Tablo 2: Birim Kök ve Durağanlık Testi Sonuçları

\begin{tabular}{|c|c|c|c|c|}
\hline & \multicolumn{2}{|c|}{ ADF Birim Kök Testi } & \multicolumn{2}{|c|}{ KPSS Durağanlık Testi } \\
\hline Değișkenler & Düzey $(\mathbf{c}+t)$ & 1. Fark (c) & Düzey $(c+t)$ & 1. Fark (c) \\
\hline$Y$ & $-1,986(0,577)$ & $-4,366(0.011)$ & 0,161 & 0,0529 \\
\hline cor & $-2,624(0,273$ & $-3,772(0,039)$ & 0,102 & - \\
\hline$I$ & $-2,731(0,234)$ & $-5,503(0,001)$ & 0,063 & - \\
\hline$C$ & $-2,927(0,174)$ & $-4,043(0,022)$ & 0,165 & 0,0521 \\
\hline enf & $-0,201(0,988)$ & $-4,170(0,017)$ & 0,168 & 0,103 \\
\hline$t r$ & $-5,079(0,002)$ & - & 0,094 & - \\
\hline $\begin{array}{c}\text { Kritik } \\
\text { Dĕ̆er(\%5) }\end{array}$ & & & \multicolumn{2}{|c|}{0,146} \\
\hline
\end{tabular}

Not: $\mathrm{c}+\mathrm{t}$ : Sabit ve Trend, c: Sabit. Olasılık değerleri parantez içinde ifade edilmiştir. ADF testi için optimal gecikme uzunluğu, Schwarz (SBC); KPSS yaklaşımı için ise, Newey-West düzeltme gecikmesi opsiyonu kullanılarak optimal gecikme sayısı belirlenmiştir

ADF birim kök testi ve KPSS durağanlık testi sonuçları Tablo 2' de sunulmuştur. ADF testi bulgularına göre; kişi başı reel gelir, yolsuzluk algısı, yatırımlar, hane halkı tüketim harcamaları ve enflasyon değişkenleri için düzeyde $\% 5$ anlamlılık seviyesinde "birim kök" vardır biçimindeki yokluk hipotezi kabul edilmekteyken, birinci farkı alındığında ise "Birim kök yoktur" biçimindeki alternatif hipotez 
kabul edilmektedir. Diğer taraftan ticari açıklık değişkeni için \%5 anlamlılık seviyesinde birim kök vardır biçimindeki yokluk hipotezi reddedilmektedir. Buna göre değişken düzeyde durağandır.

KPSS durağanlık testi sonucuna göre ise; kişi başı reel gelir, hane halkı tüketim harcamaları ve enflasyon değişkeni için \%5 anlamlılık seviyesinde "seri durağandır" biçimindeki yokluk hipotezi reddedilmektedir, yani seriler birim kök içermektedir. Diğer taraftan yolsuzluk, yatırımlar ve ticari açıklık değişkenleri için \%5 anlamlılık seviyesinde "seriler durağandır" biçimindeki yokluk hipotezi kabul edilmektedir. $\mathrm{Bu}$ bilgiler 1şı̆̆ında açıklayıcı değişkenlerin entegrasyon dereceleri birbirinden farklı olduğu söylenebilir. Eşbütünleşme ilişkisi araştırılırken, sapmalı tahminlerden kaçınmak adına bu hususların göz önünde bulundurulması önemlidir. $\mathrm{Bu}$ nedenle açıklayıcı değişkenlerin entegrasyon seviyelerinin $\mathrm{I}(1)$ ve $\mathrm{I}(0)$ biçiminde karışık olması durumunda dahi sapmasız sonuçlar veren ARDL sınır testi yaklaşımı kullanılmıştır.

Tablo 3: ARDL Tahmin Sonuçları

\begin{tabular}{|c|c|c|}
\hline & $\mathbf{F}$ & $\begin{array}{lllll}\text { \%95 Alt Sinır } & -\% 95 & \text { Üst } \\
\text { Sınır } & & & & \\
\end{array}$ \\
\hline $\operatorname{ARDL}(1,0,1,0,0,0)$ & 44,078 & 4,013 \\
\hline Uzun Dönem & Katsayı & Olasılık \\
\hline cor & $-0,010$ & 0,744 \\
\hline $\boldsymbol{I}$ & 0,156 & 0,001 \\
\hline$C$ & 0,818 & 0,000 \\
\hline enf & 0,004 & 0,405 \\
\hline$t r$ & 0,159 & 0,002 \\
\hline Sabit & $-2,584$ & 0,000 \\
\hline \multicolumn{3}{|l|}{ Hata Düzeltme Modeli } \\
\hline$\Delta c o r$ & $-0,005$ & 0,745 \\
\hline$\Delta I$ & 0,166 & 0,000 \\
\hline$\Delta C$ & 0,426 & 0,000 \\
\hline$\Delta e n f$ & 0,002 & 0,412 \\
\hline$\Delta t r$ & 0,082 & 0,000 \\
\hline ect & $-0,520$ & 0,000 \\
\hline Tanı Testleri & \multicolumn{2}{|r|}{ İstatistik [olasılık] } \\
\hline Ramsey-Reset & \multicolumn{2}{|r|}{$2,406(0,1432)$} \\
\hline Breusch-Godfrey & \multicolumn{2}{|r|}{$3,410(0,064)$} \\
\hline Breusch vd. & \multicolumn{2}{|r|}{$2,443(0,069)$} \\
\hline Jarque-Bera & \multicolumn{2}{|r|}{$0,447(0,799)$} \\
\hline $\begin{array}{l}\text { Not: Model için optim } \\
\text { belirlenmiştir. F istatistiği, }\end{array}$ & $\begin{array}{l}\text { ikme uzu } \\
\text { anmış sını }\end{array}$ & $\begin{array}{l}\text { Schwarz (SBC) bilgi kriteri vasitasıyla } \\
\text { tistiğidir. }\end{array}$ \\
\hline
\end{tabular}

ARDL sınır testinden elde edilen bulgular Tablo 3' de sunulmuștur. Elde edilen bulgulara göre ARDL sınır testi için en uygun model ARDL $(1,0,1,0,0,0)$ olarak 
belirlenmiş olup, sınır testi istatistiği 44,078 olarak hesaplanmıştır. Bu değer \%5 anlamlılık seviyesinde kritik üst sınır değerinin üzerindedir. $\mathrm{Bu}$ bağlamda "değişkenler arasında uzun dönemli ilişki yoktur" biçimindeki yokluk hipotezi \%5 anlamlılık düzeyinde reddedilmiştir. Buna göre değişkenler arasında uzun dönemli ilişki vardır ve Grafik 1 de sunulan CUSUM (cumulative sum) ve CUSUMSQ (cumulative sum of squares) testi sonuçlarına göre bu eşbütünleşme ilişkisi istikrarlıdır. Elde edilen uzun dönemli katsayılara göre yolsuzluk iktisadi büyüme üzerinde negatif fakat istatistiksel olarak anlamsız bir etkiye sahiptir. Modele kontrol değişkeni olarak dahil edilen yatırımlar, hane halkı tüketim harcamaları ve ticari açıklık değişkenleri iktisadi büyüme üzerinde beklendiği üzere pozitif ve istatistiksel olarak anlamlı bir etkiye sahiptir. Bu noktada hane halkı tüketim harcamalarının yatırımlara göre iktisadi büyüme üzerinde daha büyük bir etkiye sahip olması dikkat çekicidir. Son olarak enflasyon, Türkiye'de iktisadi büyüme üzerinde pozitif, fakat istatistiksel olarak anlamsız bir katsayıya sahiptir. Ayrıca kısa dönemli katsayılar incelendiğinde elde edilen bulguların uzun dönemli bulgular ile örtüştüğü görülmekte olup hata düzeltme teriminin katsayısı 0,520'dir. Bu bağlamda değişkenler arasında herhangi bir şok nedeniyle dengeden sapma olması halinde, sapmalar yaklaşık iki dönemde ortadan kalkmakta, bir diğer ifadeyle iki yıl sonra dengeye dönülmektedir. Ayrıca model için yapılan tanı testleri sonuçlarına göre; modelde otokorelasyon değişen varyans olmadığı ve model kurma hatası yapılmadığ $1 \% 5$ anlamlılık düzeyinde kabul edilmiştir.

Grafik 1: CUSUM ve CUSUMSQ Grafikleri

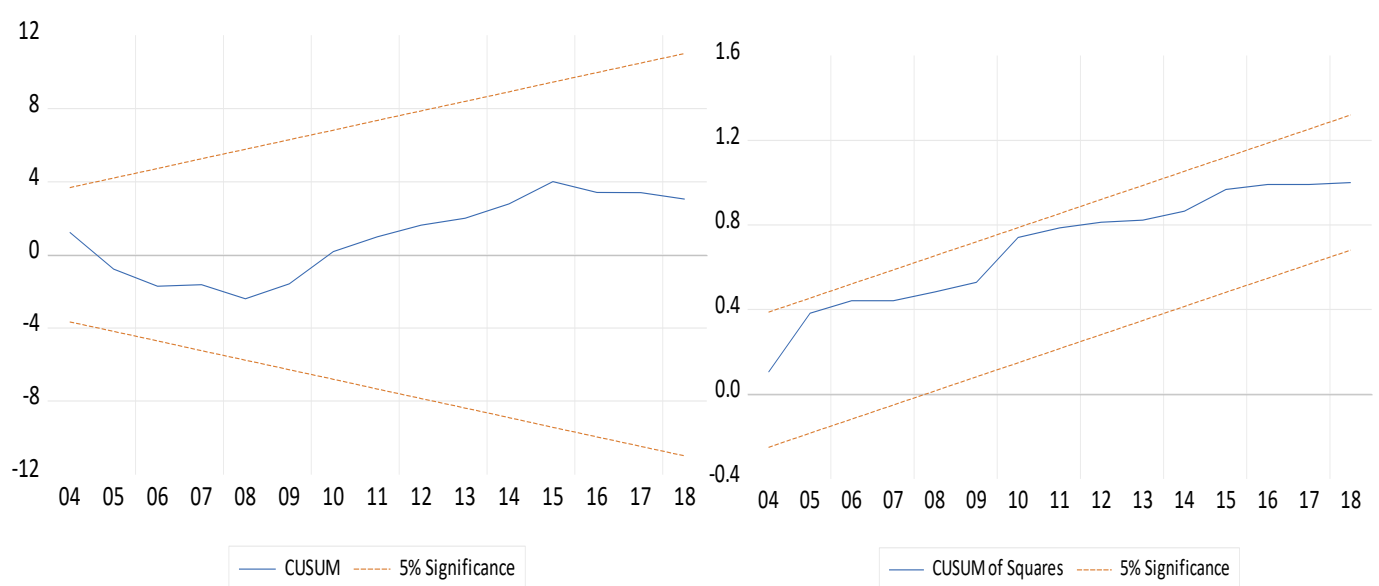

\section{Sonuç}

Yolsuzluk uzun yıllar yalnızca politik ve felsefi bağlamda ele alınmış olsa da yolsuzluk algısının ölçülebilir hale gelmesiyle ampirik analizlere de konu olmaya başlamıştır. Bu bağlamda ilgili alanda kayda değer bir uluslararası literatür oluşmuştur. Diğer taraftan Türkiye açısından oluşan literatür irdelendiğinde ise çalışma sayısının oldukça az ve genellikle nedensellik analizleri ile sınırlı olduğu 
görülmektedir. Bu çalışmada Türkiye için yolsuzluk ve ekonomik büyüme ilişkisi 1995-2018 dönemi için ARDL sınır testi yaklaşımı ile araştırılmıştır.

Elde edilen bulgular şöyle özetlenebilir: (a) yolsuzluk, enflasyon ve ekonomik büyüme arasında istatistiksel olarak anlamlı bir ilişki yoktur. (b) Yatırım, tüketim harcamaları ve ticari açıklık ile büyüme arasında ise pozitif ve istatistiksel olarak anlamlı bir ilişski mevcuttur. Bu bağlamda Türkiye'de yolsuzluk ve iktisadi büyüme arasında sistematik bir ilişki kurulamayacağı söylenebilir. Bu bilgiler 1şığında yolsuzluk Türkiye ekonomisi için ne "tekerin dönüşünü kolaylaştıran yă̆" ne de "tekerin dönüşünü zorlaştıran çakıl taşı veya kum” dur. Bu bilgiler literatürde daha önce yolsuzluk ile iktisadi büyüme arasında nedensellik ilişkisi olmadığı yönünde bulgulara erişen Karagöz ve Karagöz (2010) ile Beşel ve Savaşan' in (2014) bulgularını kısmen doğrular niteliktedir. Diğer taraftan yatırım ve tüketim harcamalarının katsayısı incelendiğinde, tüketim harcamalarının yatırım harcamalarına kıyasla daha büyük bir katsayıya sahip olduğu görülmektedir. Bu durum uzun süredir Türkiye ekonomisinde uygulanan ve 2008 Mortgage krizi sonrası artan iç talebi artırmaya yönelik politikaların bir sonucu olduğu söylenebilir. Fakat tüketim harcamaları teşvik etmenin kısa dönemde iç talebi artırma suretiyle iktisadi büyümeyi olumlu etkilese de yatırımlar gibi kalıcı istihdam, üretim bilgisi artışı ve sermaye birikimi sağlayabilen bir iktisat politikası aracı olmadığı söylenebilir. Bu açıdan karar alıcıların kalıcı istihdam ve sermaye birikimi için yatırımların milli gelir içindeki payını artırıcı tedbirler alması önemlidir.

Diğer taraftan ticari açıklık değişkeni iktisadi büyüme üzerinde pozitif etkiye sahiptir. $\mathrm{Bu}$ noktada son günlerde de sıkça tartışılan korumacı ticaret politikalarının Türkiye açısından optimal bir politika olmayacağı, dışa açılma ve ihracata dayalı büyüme modelinin iktisadi büyümeyi teşvik etmek adına daha etkin bir politika olacağı öne sürülebilir. Son olarak, çalışmada 1995-2018 arası dönemin seçilmesindeki temel kısıt yolsuzluk alg1 endeksinin 1995 yılından itibaren yayınlanmaya başlanmış olmasıdır. Bu bağlamda veri setinde zaman boyutu büyüdükçe testlerin gücünün ve boyutunun arttığı göz önünde bulundurulduğunda, gelecek çalışmalarda daha uzun zaman boyutuna sahip veriler ile Türkiye ekonomisi açısından yolsuzluk-ekonomik büyüme ilişkisinin irdelenmesi etkin politika önerileri yapılabilmesi adına önemlidir.

\section{Kaynakça}

Acaravc1, A., Akalin, G., \& Erdoğan, S. (2019). Araştırma-Geliştirme Harcamalarının Türkiye İhracatına Etkileri. Hacettepe Üniversitesi İktisadi ve İdari Bilimler Fakültesi Dergisi, 37(1), 1-16.

Akçay, S. (2002). Corroption and Ekonomic Growth: A Cross National Study. Ankara Üniversitesi SBF Dergisi, 57(01). 
Altunç, Ö. F., \& Yıldırım, A. (2017). Yolsuzluğun ekonomik büyümeyi etkileme kanalları: Ülkeler arası bir çalışma. Akademik Sosyal Araştırmalar Dergisi, 5(63), 15-27.

Arslan, Ü., \& Sağlam, Y. (2011). The relationship between corruption and public investment: The case of Turkey. Çukurova Üniversitesi Sosyal Bilimler Enstitüsü Dergisi, 20(2), 365-378.

Beşel, F., \& Savaşan, F. (2014). Türkiye'de Yapısal Kırılmalar Altında Yolsuzluk-Ekonomik Büyüme İlişkisi. Kocaeli Üniversitesi Sosyal Bilimler Dergisi, (27), 73-86.

Cieślik, A., \& Goczek, Ł. (2018). Control of corruption, international investment, and economic growth-Evidence from panel data. World Development, 103, 323-335.

Del Monte, A., \& Papagni, E. (2001). Public expenditure, corruption, and economic growth: the case of Italy. European journal of political economy, 17(1), 1-16.

Dickey, D. A., \& Fuller, W. A. (1981). Likelihood ratio statistics for autoregressive time series with a unit root. Econometrica: journal of the Econometric Society, 1057-1072.

Dreher, A., \& Gassebner, M. (2013). Greasing the wheels? The impact of regulations and corruption on firm entry. Public Choice, 155(3-4), 413-432.

Drury, A. C., Krieckhaus, J., \& Lusztig, M. (2006). Corruption, democracy, and economic growth. International political science review, 27(2), 121-136.

Ehrlich, I., \& Lui, F. T. (1999). Bureaucratic corruption and endogenous economic growth. Journal of Political Economy, 107(S6), S270-S293.

Enders, W. (2014), Applied Econometric Time Series, 4. Bask1, USA: John Wiley\&Sons, Inc.

Yılmaz, Ö., Akıncı, M., \& Erkal, G. (2014). Yolsuzluk ve İktisadi Büyüme ilişkisi: OECD ve AB Ülkeleri üzerine Panel Sınır Testi Analizi. Sayıştay Dergisi, 143-162.

Gökalp, F. M. \& Baldemir, E. (2006). Kurumsal Yapı ve Ekonomik Büyüme İlişkisi. Dokuz Eylül Üniversitesi Sosyal Bilimler Enstitüsü Dergisi, 8(1): 212226.

Huntington, S. (1968). Political order in changing societies. New Haven: Yale University Press.

Karagöz, K., \& Karagöz, M. (2010). Yolsuzluk, ekonomik büyüme ve kamu harcamaları: Türkiye için ampirik bir analiz. Sayıştay Dergisi, 76(1-3), 5-22. 
Kaufmann, D., \& Wei, S. J. (1999). Does" grease money" speed up the wheels of commerce? (No. w7093). National bureau of economic research.

Kwiatkowski, D., Phillips, P. C., Schmidt, P., \& Shin, Y. (1992). Testing the null hypothesis of stationarity against the alternative of a unit root. Journal of econometrics, 54(1-3), 159-178.

Johnson, S. (2018). Corruption is costing the global economy $\$ 3.6$ trillion dollars every year. https://www.weforum.org/agenda/2018/12/the-global-economyloses-3-6-trillion-to-corruption-each-year-says-u-n (Erişim Tarihi: 24.09.2019).

Mauro, P. (1995). Corruption and growth. The quarterly journal of economics, 110(3), 681-712.

Narayan, P. K. (2005). The saving and investment nexus for China: evidence from cointegration tests. Applied economics, 37(17), 1979-1990.

Ozturk, I., \& Acaravci, A. (2013). The long-run and causal analysis of energy, growth, openness and financial development on carbon emissions in Turkey. Energy Economics, 36, 262-267.

Pesaran, M. H., \& Shin, Y. (1998). An autoregressive distributed-lag modelling approach to cointegration analysis. Econometric Society Monographs, 31, 371413.

Pesaran, M. H., Shin, Y., \& Smith, R. J. (2001). Bounds testing approaches to the analysis of level relationships. Journal of applied econometrics, 16(3), 289326.

Sharma, C., \& Mitra, A. (2019). Corruption and Economic Growth: Some New Empirical Evidence from a Global Sample. Journal of International Development, 31(8), 691-719.

Shleifer, A., \& Vishny, R. W. (1993). Corruption, the quarterly journal of economics, 599-617.

Sofuoğlu, E., Kızılkaya, O., \& Ay, A. (2017). Yolsuzluk ve Ekonomik Büyüme Arasındaki İlişki: Yeni Sanayileşmiş Ülkeler için Panel Veri Analizi. International Conference On Eurasian Economies. 2017: 476-482.

Swaleheen, M. (2011). Economic growth with endogenous corruption: an empirical study. Public Choice, 146(1-2), 23-41.

Transparency International (2017). People and Corruption: Citizen's Voices From Around The World. https://www.transparency.org/whatwedo/publication/people_and_corruption_c itizens_voices_from_around_the_world (Erişim Tarihi: 24.09.2019).

Transparency International (2019a). What is corruption. https://www.transparency.org/what-is-corruption. (Erişim Tarihi: 25.08.2019). 
Transparency International (2019b). Corruption Perception Index. https://www.transparency.org/research/cpi/overview. (Erişim Tarihi: 27.09.2019).

United Nations (2018). Global Cost of Corruption at Least 5 Per Cent of World Gross Domestic Product, Secretary-General Tells Security Council, Citing World Economic Forum

Data. https://www.un.org/press/en/2018/sc13493.doc.htm (Erişim Tarihi: 24.09.2019).

Wei, S. J. (1999). Corruption in economic development: Beneficial grease, minor annoyance, or major obstacle?. The World Bank.

World Bank (1997). Helping countries combat corruption: The role of the World Bank.

http://www1.worldbank.org/publicsector/anticorrupt/corruptn/corrptn.pdf. (Erişim Tarihi: 25.08.2019).

World Bank (2019). World Development Indicators. https://databank.worldbank.org/source/world-development-indicators (Erişim Tarihi: 26.09.2019). 